\title{
Building a value-based human resource management system
}

\author{
Tatiana Gaponenko ${ }^{1, *}$, Viktoriya Dovbysh ${ }^{2}$, Nikolay Filin $^{3}$, and Raykhana Bulatova ${ }^{3}$ \\ ${ }^{1}$ Don State Technical University, Gagarin square, 1, 344003 Rostov-on-Don, Russia \\ ${ }^{2}$ Volgodonsk engineering and technical Institute-branch of the National research nuclear University \\ "MEPhI", Lenin str., 73/94, 346360 Volgodonsk, Russia \\ ${ }^{3}$ Rostov state University of Economics, Bolshaya Sadovaya str., 69, 344002 Rostov-on-Don, Russia
}

\begin{abstract}
The aim of the study is to develop a value-based approach to the management of organizational staff, which involves the management of employee behaviour through the development of a commitment to corporate values, which will improve the quality and efficiency of the management. The methods of analogy, expert assessment, estimating the efficiency of the investment project, the coefficient method, the direct method of estimating the value of human capital by the cost approach are used. The result of the study is a methodology for studying corporate and personal values, as well as a system of indicators to measure the effectiveness of decisions taken in the area of value-based personnel management. It is proposed to measure the impact of value-based staff management in three ways: by the results achieved through the commitment to individual values; as a degree of achievement of management objectives; as the efficiency of investment in personnel. The system of value-based personnel management presented was tested in the context of an agricultural organization, for which it was proposed that the personnel management system be reoriented from goalbased management to value-based management. The effectiveness of the proposed solutions has been assessed through the developed system of indicators.
\end{abstract}

\section{Introduction}

The modern world is facing a systemic crisis due to the completion of one major economic cycle based on industrialization and the transition to the next cycle, in which economic and social relations are defined by informatization and communication technological and communicative technologies. Owing to fundamental changes in the economy and society, the old paradigm cannot meet today's challenges. This also applies to labour relations - there are changes in the content of work, the requirements of the individual, the methods of organization and use of work, the approach to education and even the perception of work and employment [1-2]. Tendencies towards individualization of work are becoming more expressed [3] and, on the other hand, the requirements of employers already extend not only to the skills of the staff, but also to the personal qualities of the employees and their psychophysiological characteristics. This determines the relevance of the development of

*Corresponding author: gaponenko.t@mail.ru 
new approaches to the management of the organization's staff, taking into account the personal needs of employees and their relevance to corporate requirements.

In modern changing world instructions and business processes become obsolete faster than formalized, and goals and job evaluation criteria change before an ordinary professional can become accustomed to them. There is an increasing need for a firm foundation of simple and understandable rules of engagement between staff and the organization, the organization and the external environment. These simple rules become the key values of the organization - the guiding principles of functioning, simple rules for making managerial decisions, by which you can determine what is really important and significant for the development of the organization, and what is insignificant at any given time. Management By Values (MBV) is a response to the need for creative solutions to complex issues in an unstable external environment. The development of value-based management involves the development of creative leadership as the competence of managers. This makes it possible to achieve productivity growth and to implement the necessary innovative changes in the organization's activities. Creativity in the work of not only leaders, but also staff [4,5] becomes important, and creativity is always based on personal qualities and qualities. This explains the growing interest in the research of personal values and individual motivational factors [6,7].

The classifications of organizational values presented in the literature are based on known classifications of personal values [8,9]. Digitization modifies people's behaviour and values, but on the other hand it gives more possibilities to study personal requests. "Personal electronic devices including smartphones give access to behavioural signals that can be used to learn about the characteristics and preferences of individuals» [10]. The ability to handle personnel big data with blockchain is emerging, which significantly increases the ability to manage [11]. The digital future relates to the management's orientation towards the values and needs of the individual [12,13], and in the development of artificial intelligence and robots, human values are embedded in them [14].

MBV is a growing area of Russian management. The lack of clear guidelines for the application of the concept has impeded its wide dissemination. The aim of the article is to develop the methodological aspects of personnel management based on a value-based approach, which will make it possible to develop a motivational system of staff values that is most in line with the corporate spirit and direction of development. The Values Office provides indirect incentives for staff work, contributing to productivity gains, unleashing creative potential.

\section{Materials and methods}

The methodological foundations of value-based management are:

- scientific methods for identifying corporate and personal values. Special surveys, biographical interviews, the purpose of which is to define personal philosophy, system of attitudes (needs, determinant), "basic" personal elections can be used. This study uses the interview method to identify corporate values and the survey method to identify personal values;

- indicators of value and anti-value behavior in a particular organization. It is proposed to use methods of data collection and comparative analysis that make it possible to distinguish the attitudes of the interviewees towards certain values, in particular, methods of analogy, content analysis and expert analysis.

Management impact should be organized in such a way that the values of workers are not formed spontaneously by random factors, but within a chosen concept, ideology. Currently, the methods of UWES A. Bakker and «Scale of job crafting» M. Tims, A. Bakker, D. Derks [15] are known, which allow to assess the impact of the staff in the work. In our point of view, a more in-depth study of the values that underlie the behavior of workers, as well as 
the requirements of workers, will make the management of staff more meaningful, indicating the direction of staff development. For this purpose, a methodology has been developed for identifying corporate and personal values. Its implementation is based on an indirect approach, which does not directly define an employee's attitude to values, but indirectly, which exposes staff attitudes to values through their behavioral attitudes

The proposed methodology is based on the following conditions:

- values are the features, qualities and behavior patterns that an organization values in its employees (corporate values), on the one hand, and staff wish to implement in the organization (personal values), on the other;

- the success of an organization is determined by the match in personal and corporate values; - the divergence of personal and corporate values can be overcome through the development of personal values, which should bring employees' personal values as close as possible to what the organization expects from them (corporate values). If this goal cannot be achieved, the employee cannot be successfully implemented in the organization, and the organization cannot effectively use his skills for his needs, so the employee is looking for another job.

The study of values should be conducted in two aspects: corporate values and personal values, as shown in figure 1 . Corporate values are set by owners and/or top managers, and personal values are set by performers.

MAIN HIGHLIGHTS

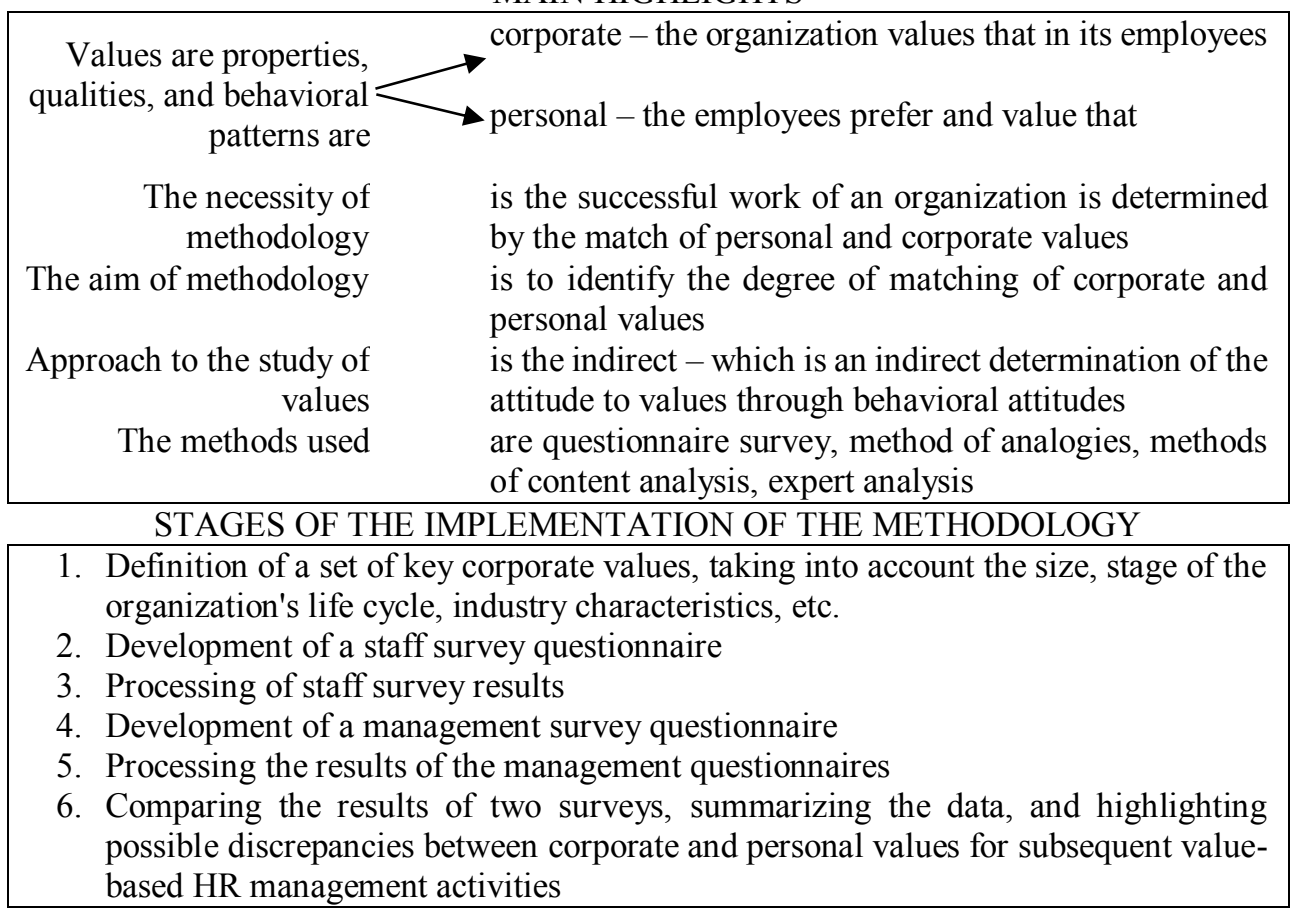

Fig. 1. Methodology of studying corporate and personal values

The impact of value-based staff management is proposed to be assessed in three ways:

1) by the results achieved through the commitment to individual values.

2) as a degree of achievement of management objectives.

3 ) as the efficiency of investment in personnel, then the evaluation of management results is the evaluation of the efficiency of the investment project. 
Management performance indicators for selected values are defined after the corporate values set of the organization has been established. For example, indicators of the result of personnel management based on the value of "thrift" can be:

- power consumption: share of electricity costs in production costs;

- energy cost per full-time unit (electricity per staff member of the organization);

- environmental costs per full-time unit (environmental charges (including garbage removal) per staff member).

At the management on the value of "the prestige of the organization" the result can be an increase in the rating of the organization in social networks, ratings.

The management result for each value can be determined similarly.

The results of staff management can also be viewed from the perspective of achieving organizational goals with regard to staff.

Such personnel management objectives may be:

- a reduction in the number of staff employed under the same organizational conditions. In this case, the organization could achieve savings by reducing staff costs;

- increase in profits with the same level of human capital. In this case, the profit-to-staff ratio can be calculated, or the return per employee;

- a reduction in the use of human capital at the same level of return. This is a result of improved efficiency in the use of human capital;

- reducing the cost of raising human capital or of finding and selecting creative staff.

Therefore, a value-based approach for the evaluation of personnel management is proposed, consisting of three sets of indicators that reflect both the cumulative assessment of staff management and the management results for individual values. This will capture and integrate heterogeneous approaches to measuring the performance of human capital management, as well as the specificity of value management through the introduction of value-based indicators (the values themselves are determined by each organization in the design of its individual personnel management system).

\section{Results}

In general, the process of implementing value-aimed HR management can be described as follows, figure 2 .

Values serve as a guide to employee behaviour. On the one hand, they are universal, because people's behaviors are guided by moral categories, for example, they can be clarity, reliability, fairness, thrift. On the other hand, each organization has an individual set of values that reflects sectoral, market and other activities, a set of key corporate values, taking into account the size, stage of the life cycle of the organization, characteristics of the industry, etc.

Based on the experience and study of the economic literature $[8,9]$ a set of key corporate values from the agricultural organization was developed, table 1. 
Formation of a set of corporate values

Identification of personal values of employees of the organization

Analysis of the coincidence of corporate and personal values

Development and realization of a program for the development of the necessary values among employees with creative abilities

Effectivenes evaluation of the desicions taken

Fig. 2. Steps to implement value-based human-resource management

Table 1. Key corporate values of an agricultural organization

\begin{tabular}{|c|c|}
\hline Value & Description \\
\hline Work stability & $\begin{array}{l}\text { Most staff agree that working in a stable team is more efficient and } \\
\text { effective }\end{array}$ \\
\hline Professionalism & $\begin{array}{l}\text { High professional competence ensures respect and career } \\
\text { development }\end{array}$ \\
\hline Social security & $\begin{array}{l}\text { The employer is responsible for the health and welfare of his } \\
\text { employees }\end{array}$ \\
\hline Unity and cohesion & $\begin{array}{l}\text { The employee feels part of the team and responsible for the end } \\
\text { result of the organization }\end{array}$ \\
\hline Thrift & $\begin{array}{l}\text { Employees understand that saving resources affects an } \\
\text { organization's income and contributes to its financial well-being }\end{array}$ \\
\hline Care of staff & $\begin{array}{l}\text { The employer shall ensure conditions for safe and comfortable } \\
\text { work }\end{array}$ \\
\hline $\begin{array}{l}\text { Prestige of the } \\
\text { organization }\end{array}$ & $\begin{array}{l}\text { Working in an organization enhances an employee's self-esteem } \\
\text { and therefore attracts professionals }\end{array}$ \\
\hline $\begin{array}{ll}\text { Respect } & \text { for } \\
\text { traditions } & \end{array}$ & $\begin{array}{l}\text { Most staff understand that organizational success is } \\
\text { intergenerational and results-based }\end{array}$ \\
\hline $\begin{array}{l}\text { Readiness to cope } \\
\text { with change }\end{array}$ & $\begin{array}{l}\text { Staff are aware that the current environment requires continuous } \\
\text { updating of technologies, products in response to the changing } \\
\text { needs of buyers, so they are ready and interested in adopting new } \\
\text { techniques and working methods, developing new products }\end{array}$ \\
\hline $\begin{array}{l}\text { Pursuit } \\
\text { development }\end{array}$ & Most staff are committed to improving and developing their skills \\
\hline
\end{tabular}

Two questionnaires have been developed for the identification of values - for the identification of corporate values and for the identification of personal values. The 
questionnaires consist of carefully worded questions, with three to nine options for one or more of the values in the proposed list, table 1. The personnel questionnaire fragment is presented in figure 3 . The answers to the questions in table 1 , will highlight key values of the staff as well as those values that have not been given sufficient attention.

\begin{tabular}{|l|l|l|}
\hline Emerging values & Question & Answer options \\
\hline $\begin{array}{l}\text { Stability of work, } \\
\text { Social security } \\
\text { prestige of the } \\
\text { organization, } \\
\text { development } \\
\text { readiness }\end{array}$ & $\begin{array}{l}\text { Why do you work for } \\
\text { the company? } \\
\text { (no more than three } \\
\text { answers) }\end{array}$ & $\begin{array}{l}\text { - stable work } \\
\text { - stable salary } \\
\text { - the company became my second } \\
\text { home } \\
\text { - it's prestigious to work here } \\
\text { - there was no better alternative } \\
\text { - there is a social package } \\
\text { - career growth is possible here }\end{array}$ \\
& $\begin{array}{l}\text { - interested in new experience } \\
\text { - my parents worked here }\end{array}$ \\
\hline Unity and cohesion & $\begin{array}{l}\text { What do you consider } \\
\text { your collective? } \\
\text { (one response option) }\end{array}$ & $\begin{array}{l}\text { - the whole enterprise } \\
\text { - my own shop/manufacture } \\
\text { - my own group } \\
\text { - my own shift }\end{array}$ \\
\hline Work stability & $\begin{array}{l}\text { How many years would } \\
\text { you like to work at this } \\
\text { enterprise (one answer) }\end{array}$ & $\begin{array}{l}\text { - for the rest of the life } \\
\text { - one or two years } \\
\text { - from five to ten years } \\
\text { - it depends }\end{array}$ \\
\hline
\end{tabular}

Fig. 3. Personal Values Survey (for staff of the organization)

A value-based approach to personnel management should be implemented at the recruitment stage. Recruitment and selection guidelines should be developed to reflect corporate values, and further, if the personal values of a candidate for a vacant post and corporate values are sufficiently similar, During the period of adaptation in the new workplace, it is possible to achieve a further overlap. For this purpose, the programmes for the development of corporate values (trainings, seminars, etc.) are being developed and implemented.

When there is convergence between the values that the organization wishes to see in the staff and those that the staff members themselves consider to be necessary and important, the conditions are in place for the most efficient use of staff.

\section{Discussion of the results}

The considered value-oriented approach to personnel management was realized in conditions of agricultural organization ZAO Vishnevskoe (Vishnevskoe, CJSC), which is engaged in grain and oilseeds cultivation, processing of agricultural products.

To determine corporate values, an interview was conducted with the director of the organization, who is also the sole owner of the organization. The interview found that the set of corporate values was consistent with what was described earlier in table 1, and the director was provided with a questionnaire to identify corporate values. Further, a staff survey was conducted on the basis of a developed personal values questionnaire. Forty questionnaires were distributed, 35 of which were returned, making 81.4 per cent of staff interviewed.

When answering the first question "Why do you work at the enterprise?" the answers 
were distributed as follows (figure 4).

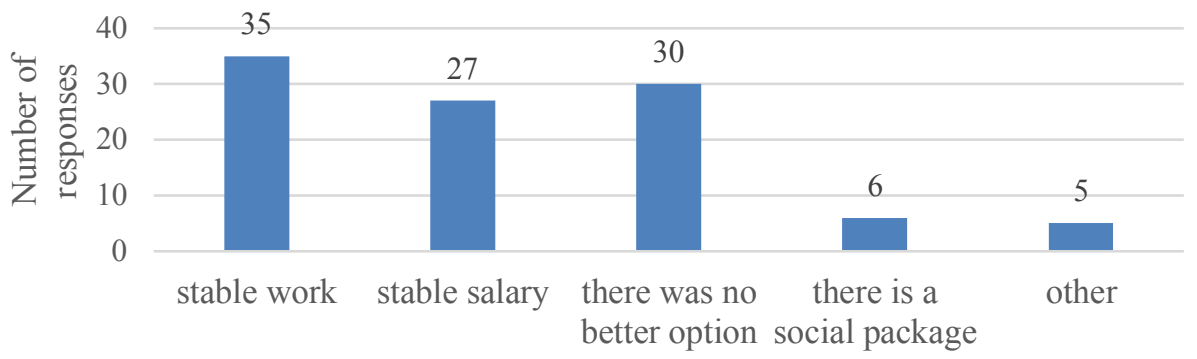

Fig. 4. Distribution of answers to the question "Why do you work at the enterprise?"

The employees have demonstrated the importance of the value of "stability of work". But almost $86 \%$ (30 out of 35 respondents) said that they worked for the company because there was no better alternative. This means that the enterprise does not correspond to their value "prestige". It can be expected that employees are not proud of their enterprise, which means that they will not have a deep interest in its development.

When answering the first question "What do you consider your collective?" the answers were distributed as follows (figure 5).

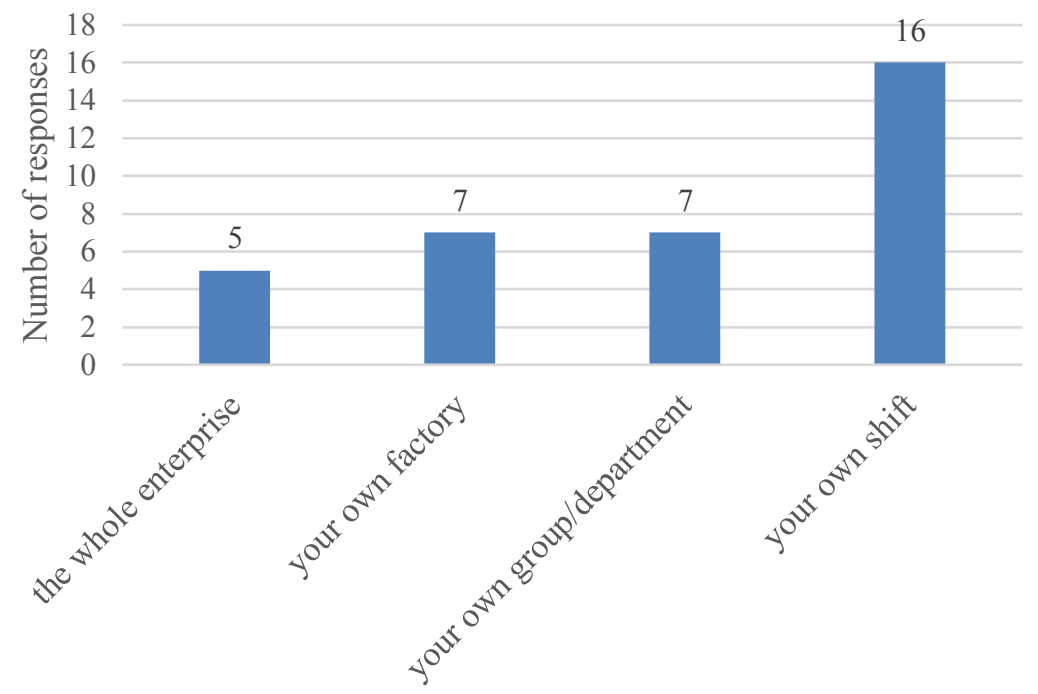

Fig. 5. Distribution of answers to the question "What do you consider your collective?"

The distribution of responses shows that the majority $(86 \%)$ consider their team only their shift or group, department, workshop, and almost $2 / 3$ employees $(66 \%)$ very narrowly delineate their team - only the circle with whom they come into contact for work. The whole enterprise is perceived by only five people as a collective. This indicates a low level of employee involvement.

When answering the question "How many years would you like to work at this enterprise?" 28 people (80\%) replied "As many as we can", and the remaining 7 people $(20 \%)$ chose the answer - "5-10 years". This shows, on the one hand, that no one plans to devote their lives to the enterprise, and, on the other, that there is no certainty of the future, no certainty of the stability of life (therefore, when answering the first question it was revealed that many people are important value "stability" because there is a lack of it). 
Analysis of answers to the question "How do you assess the professional abilities of your colleagues?" found that the team was not strong enough, as many did not consider their colleagues to be sufficiently professional.

When answering the question "What qualities do you respect your colleagues for?" such replies as "readiness to come to help", "professional abilities", "responsible attitude to work" were mostly received. Such values as "kindness and soul", "ability to create a good atmosphere" were selected only in 5\% of cases, also met answers "I do not respect colleagues" (4\%), "I am indifferent to colleagues" (3\%), which speaks about the lack of cohesion of the team.

When answering the question "If you were asked to change jobs with the same level of earnings, what conditions did you agree to a new job under?" employees indicated that they wanted better working conditions, more social support, work closer to home.

When answering the question "Do you often have to wait for the results of the work of other employees before you start solving your tasks?", $86 \%$ chose the answer "We often do this", which means that the company does not observe the principle of time economy.

When answering the question "Do you often have to redo your work or the work of other employees?", 83\% chose the answer "sometimes", which positively characterizes the organization of work.

When answering the question "How do you assess the attitude of management and colleagues to yourself?" the majority (77\%) believe that it is not appreciated enough.

When answering the question "How do you feel about separate collection of garbage?", which reflects the worldview of a person and his attitude to nature, ecology, $77 \%$ said that they will divide garbage only under the threat of a fine, and this indicates a lack of thrift.

The answers to the question "What is your opinion about production veterans?" reveal the importance of respect for traditions. $66 \%$ of respondents chose the answer "these are the most loyal people to the organization", and this indicates that employees at the enterprise value respect for traditions.

The most popular answers to the question "What are the working conditions of friends, relatives, acquaintances make you envious?" (no more than three responses could be selected, with a total of 105 responses received from 35 respondents) were:

- confidence in a stable job and earnings (35\%);

- comfortable vacation $(10 \%)$;

- career opportunities $(10 \%)$

- additional health insurance (8\%).

Therefore, the main value for employees is confidence in stable earnings and stable work, as well as the possibility of career growth, additional medical insurance, and convenient vacation.

The answers to the question "Should an employee report about mistakes made by other employees to the manager?" were distributed as follows: $65 \%$ - no, because this will lead to quarrels in the team, $10 \%$ - yes, because the elimination of errors leads to an improvement in the work of the entire organization, $25 \%$ - only if production standards are violated, which can lead to the release of low-quality and even dangerous products for the consumer. In this way, employees do not see their connection with the company as a whole, its reputation, because $90 \%$ are ready not to inform the management about possible violations in production, and only $10 \%$ understand the importance of joint efforts to ensure product quality.

Answers to the question "Are you ready to acquire new work skills, even if not in your profession?" we found a low interest of employees of ZAO Vishnevskoe (Vishnevskoe, CJSC) in new knowledge and skills, as only 6 people (17.1\%) are ready for new knowledge, and $51.4 \%$ perceive them only as a need to save their jobs, and not as prospects, opportunities, $31.5 \%$ of respondents do not see the need for new knowledge and skills, mostly people of pre-retirement age or workers. 
The answers to the question "Do you agree to try yourself in another post (with the same earnings and working conditions)?", which reveals a willingness to change, were distributed, as shown in figure 6 . The results show the conservatism of workers, as most of them are not ready for change.

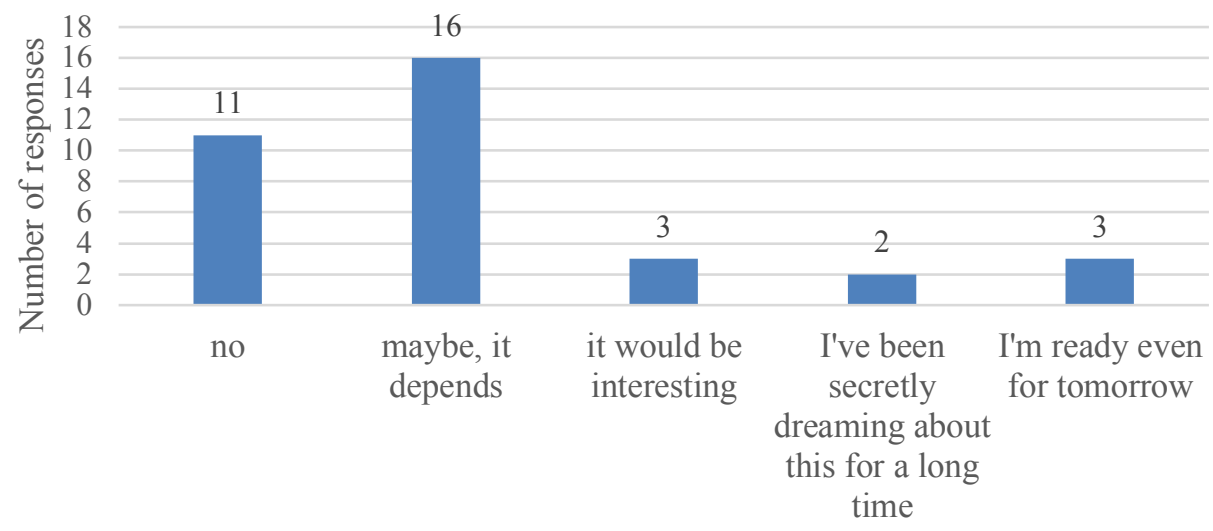

Fig. 6. Distribution of answers to the question "Do you agree to try yourself in another post (with the same earnings and working conditions)?"

Answers to the last question "How do you plan to spend your vacation?" also revealed the passivity of employees, since only $3 \%$ of employees are ready to go to a new place, and the rest preferred to stay at home or go to a well-known place.

The Analysis of the results of the identification of corporate and personal values is presented in Table 2.

Table 2. Analysis of the results of the identification of corporate and personal values in ZAO

Vishnevskoe (Vishnevskoe, CJSC)

\begin{tabular}{|c|c|c|c|}
\hline Value & Staff attitude & $\begin{array}{l}\text { Owner's } \\
\text { (leader's) } \\
\text { attitude }\end{array}$ & $\begin{array}{l}\text { Conclusion about the } \\
\text { match of corporate and } \\
\text { personal values }\end{array}$ \\
\hline Work stability & $\begin{array}{l}\text { Is the most } \\
\text { recognized value }\end{array}$ & $\begin{array}{l}\text { Is the most } \\
\text { recognized } \\
\text { value }\end{array}$ & $\begin{array}{l}\text { There is a match, but staff } \\
\text { value job stability more } \\
\text { than it matters to the } \\
\text { supervisor }\end{array}$ \\
\hline Professionalism & $\begin{array}{l}\text { Is a recognized } \\
\text { value }\end{array}$ & $\begin{array}{l}\text { Is a recognized } \\
\text { value }\end{array}$ & There is a match \\
\hline Social security & $\begin{array}{l}\text { Is a recognized } \\
\text { value }\end{array}$ & $\begin{array}{l}\text { Is a recognized } \\
\text { value }\end{array}$ & There is a match \\
\hline Unity and cohesion & $\begin{array}{l}\text { Lack of } \\
\text { awareness, } \\
\text { fragmentation of } \\
\text { staff, holistic } \\
\text { vision of the } \\
\text { organization and } \\
\text { its place }\end{array}$ & $\begin{array}{l}\text { Is not an } \\
\text { important value }\end{array}$ & $\begin{array}{l}\text { There is a match, the } \\
\text { manager values unity and } \\
\text { cohesion less than the } \\
\text { employees }\end{array}$ \\
\hline
\end{tabular}




\begin{tabular}{|c|c|c|c|}
\hline Thrift & $\begin{array}{l}\text { Not sufficiently } \\
\text { felt }\end{array}$ & $\begin{array}{l}\text { Is highly } \\
\text { appreciated }\end{array}$ & $\begin{array}{l}\text { There is no match, the } \\
\text { manager is much more } \\
\text { interested in thrift than the } \\
\text { employees }\end{array}$ \\
\hline Care of staff & $\begin{array}{l}\text { Recognized as } \\
\text { high value }\end{array}$ & $\begin{array}{ll}\text { Is not } & \text { npreciated } \\
\text { enough } & \end{array}$ & $\begin{array}{l}\text { There is no match, } \\
\text { employees attach more } \\
\text { importance to this value } \\
\text { than the manager }\end{array}$ \\
\hline $\begin{array}{l}\text { Prestige of the } \\
\text { organization }\end{array}$ & Is not significant & Is appreciated & $\begin{array}{l}\text { There is no match, the } \\
\text { manager values the prestige } \\
\text { of the organization much } \\
\text { more than the employees }\end{array}$ \\
\hline $\begin{array}{l}\text { Respect for } \\
\text { traditions }\end{array}$ & Is appreciated & Undervalued & $\begin{array}{l}\text { There is no match, } \\
\text { employees attach more } \\
\text { importance to this value } \\
\text { than the manager }\end{array}$ \\
\hline $\begin{array}{l}\text { Readiness to cope } \\
\text { with change }\end{array}$ & $\begin{array}{l}\text { No particular } \\
\text { importance is } \\
\text { attached }\end{array}$ & $\begin{array}{l}\text { No particular } \\
\text { importance is } \\
\text { attached }\end{array}$ & There is a match \\
\hline $\begin{array}{l}\text { Pursuit of } \\
\text { development }\end{array}$ & $\begin{array}{l}\text { No particular } \\
\text { importance is } \\
\text { attached }\end{array}$ & $\begin{array}{l}\text { Is a matter of } \\
\text { some } \\
\text { importance }\end{array}$ & $\begin{array}{l}\text { There is no match, the } \\
\text { manager values the desire } \\
\text { to develop much more than } \\
\text { the employees }\end{array}$ \\
\hline
\end{tabular}

The application of the methodology for identifying corporate and personal values in ZAO Vishnevskoe (Vishnevskoe, CJSC) allows us to conclude that not all corporate and personal values are the same. There is an underestimation on the part of the management of traditions, care for employees, unity and cohesion. On the other hand, employees are not sufficiently aware of the importance of thrift, development, and do not sufficiently appreciate the prestige of work in their organization.

For effective economic activity, it is necessary to reorient personnel management from results-based management to values-based management. This requires:

- the articulation of corporate values and their dissemination to employees;

- increasing the value of human capital by developing new skills of employees, especially online sales skills as a new form of sales organization for the organization;

- encouraging employees to develop independently;

- making changes to the system of incentives and bonuses;

- paying for advanced training courses for those employees whose valuable skills and abilities can be developed;

- conducting training on team cohesion;

- maintaining a corporate culture;

- promoting the importance of thrift, unity, and cohesion.

The planned results of the personnel management of ZAO Vishnevskoe (Vishnevskoe, CJSC) based of value-aimed management are presented in Table 3.

Table 3. Performance assessment of personnel management of ZAO Vishnevskoe (Vishnevskoe, CJSC) based on value-aimed management

\begin{tabular}{|c|c|c|c|c|}
\hline Indicator & Base value & $\begin{array}{c}\text { Project } \\
\text { value }\end{array}$ & $\begin{array}{c}\text { Growth rate, } \\
\%\end{array}$ & Conclusion \\
\hline \multicolumn{5}{|c|}{ Indicators which characterize certain values } \\
\hline Power consumption & 0,043 & 0,034 & $-21,0$ & the rise of thrift \\
\hline
\end{tabular}




\begin{tabular}{|c|c|c|c|c|}
\hline $\begin{array}{l}\text { Energy cost per full- } \\
\text { time unit, thousand } \\
\text { rubles/person. }\end{array}$ & 28,37 & 22,54 & $-20,5$ & the rise of thrift \\
\hline $\begin{array}{l}\text { Environmental costs } \\
\text { per full-time unit, } \\
\text { thousand } \\
\text { rubles/person. }\end{array}$ & 3,37 & 3,30 & $-10,8$ & the rise of thrift \\
\hline $\begin{array}{l}\text { Percentage of staff } \\
\text { with improved } \\
\text { skills, \% }\end{array}$ & 0 & 4,5 & 100,0 & $\begin{array}{l}\text { Acceptance of the } \\
\text { value of "Striving for } \\
\text { development" }\end{array}$ \\
\hline $\begin{array}{l}\text { Share of profit on } \\
\text { implementing new } \\
\text { products, } \%\end{array}$ & 0 & 11,1 & 100,0 & $\begin{array}{l}\text { Acceptance of the } \\
\text { value of "Striving for } \\
\text { development" }\end{array}$ \\
\hline \multicolumn{5}{|c|}{ Degree of achievement of management goals } \\
\hline $\begin{array}{l}\text { Impact of staff } \\
\text { utilization, thousand } \\
\text { rubles/person. }\end{array}$ & 39,1 & 50,1 & 28,1 & $\begin{array}{l}\text { Increased } \\
\text { productivity per staff }\end{array}$ \\
\hline $\begin{array}{l}\text { The cost of human } \\
\text { capital (in the } \\
\text { estimation of the } \\
\text { cost approach), } \\
\text { thousand rubles. }\end{array}$ & 8179 & 8759 & 7,1 & $\begin{array}{l}\text { Growth with positive } \\
\text { effects }\end{array}$ \\
\hline \multicolumn{5}{|c|}{ Performance indicators of investment in staff } \\
\hline $\begin{array}{l}\text { Net Present Value } \\
(\mathrm{NPV}) \text {, rubles. }\end{array}$ & 0 & 208920 & $X$ & $\begin{array}{l}\text { Since NPV }>0 \text {, the } \\
\text { project is effective }\end{array}$ \\
\hline $\begin{array}{ll}\text { Profitability } & \text { of } \\
\text { investments (PI) }\end{array}$ & 1 & 1,27 & $X$ & $\begin{array}{l}\text { Since PI }>1 \text {, the } \\
\text { project is effective }\end{array}$ \\
\hline $\begin{array}{lrr}\text { Internal rates } & \text { of } \\
\text { return (IRR), } \% & \end{array}$ & 49,5 & 27,84 & $X$ & $\begin{array}{l}\text { The indicator is } \\
\text { higher than the base } \\
\text { level, so we need to } \\
\text { look for cheaper } \\
\text { sources of investment }\end{array}$ \\
\hline $\begin{array}{ll}\text { Payback } & \text { periods } \\
(\text { РP), лет } & \\
\end{array}$ & 3 & 1,25 & $X$ & $\begin{array}{l}\text { Payback during } \\
\text { statutory period }\end{array}$ \\
\hline
\end{tabular}

The study of the achieved results shows that the vast majority of the presented indicators are improving, which indicates the feasibility of introducing the provisions of value-aimed management in the activities of an agricultural organization.

\section{Conclusion}

The article develops methodological recommendations for the human resources management of an agricultural organization based on a value-based approach. That will ensure the regulation of employee behavior through values and therefore will improve the quality and effectiveness of the organization's management. The practical realization of the ways and methods of personnel management, which are based on the conditions of value-oriented management, proves their effectiveness. Experimental results were reached that are essential for the development of the theory and practice of the organization's management. According to the results of the research, it is proven that the introduction of new methods of value-aimed 
management is highly effective and allows you to yield high returns from the organization's investments in the development of staff.

\section{References}

1. A. Hines, Foresight and STI Governance 13(1), 19-30 (2019) doi:10.17323/25002597.2019.1.19.30

2. K. Barmuta, O. Grishchenko, E3S Web of Conferences 175, 08003 (2020) doi:10.1051/e3sconf/202017508003

3. T. Gaponenko, S. Muradova, V. Litvinova, E3S Web of Conferences 175, 15003 (2020) doi:10.1051/e3sconf/202017515003

4. S. Naseer, U. Raja, F. Syed, M. B.L. Donia, Wendy Darr, The Leadership Quarterly 27(1), 14-33 (2016) doi:10.1016/j.leaqua.2015.09.005.

5. W. Chi-Kwan Chiu, V. Miu-Chi Lun, M. H. Bond, Journal of Cross-Cultural Psychol 49, 239-260 (2018) doi:10.1177/0022022116651336

6. A. D. Fave, L. Negri, P. R. Manohar, A. Morandi, M. Bassi, European Journal of Integrative Medicine 7, 4396-408 (2015) doi:10.1016/j.eujim.2014.09.133

7. M. Mahjoub, S. Atashsokhan, M. Khalilzadeh, A. Aghajanloo, S. Zohrehvandi, Procedia Computer Science 138, 764-774 (2018) doi:10.1016/j.procs.2018.10.100

8. V. V. Gouveia, T. L. Milfont, V. M. Guerra, Personality and Individual Differences 68, 250-253 (2014) doi 10.1016/j.paid.2014.03.025

9. K. Hoff, J. E.Stiglitz, Journal of Economic Behavior \& Organization 126(B), 25-57 (2016) doi:10.1016/j.jebo.2016.01.005

10. K. Kalimeri, M. G.Beiró, M. Delfino, R. Raleigh, C. Cattuto, Computers in Human Behavior 92, 428-445 (2019) doi:10.1016/j.chb.2018.11.024

11. J. Chen, Z. Lv, Houbing Song, Future Generation Computer Systems 101, 1122-1129 (2019) doi:10.1016/j.future.2019.07.037

12. K. Alam, M. Odei, Erdiaw Kwasie, Md Shahiduzzaman, Barbara Ryan, Journal of Rural Studies 60, 60-69 (2018) doi:10.1016/j.jrurstud.2018.02.009

13. R. G. Eccles, I. Ioannou, G. Serafeim, Management Science, 60(11), 2835-2857 (2014) doi: 10.1287/mnsc.2014.1984

14. L. Gazzaneo, A. Padovano, S. Umbrello, Procedia Manufacturing, 42, 219-226 (2020) doi:1016/j.promfg.2020.02.073

15. M. Tims, A. B.Bakker, D. Derks, Journal of Vocational Behavior, 80, 173-186 (2012) doi:10.1016/j.jvb.2011.05.009 